\title{
Raising Redeemable Capital through Mushārakah TFCs: A Case of Quasi Equity for Corporate Financing
}

\author{
Zohra Jabeen $^{1 *}$, Shafiullah Jan ${ }^{2}$, Romana Bangash ${ }^{3}$ \\ ${ }^{1,3}$ Assistant Professors at the Institute of Management Sciences Peshawar, Pakistan \\ 2 Assistant Professor and Research Chair of Centre for Excellence in Islamic Finance, \\ Institute of Management Sciences Peshawar, Pakistan
}

\section{Keywords}

Mushārakah

Term Finance Certificate

Shari'ah

Quasi Equity

\begin{abstract}
This narrative study depicts the situation of a company whose founding CEO wanted to extricate the company from the interest-based borrowing and deputed its CFO to find a way out through any mode compliant to the Shari 'ah, so to retire its existing debt and also to get further financing through Islamic modes of financing. The study discusses the scenario and further the reasons and modalities of choosing a mode of financing i.e. mushärakah based Term Finance Certificates (MTFCs). The study develops a deeper understanding of the transition from interest-based financing to the development of MTFC, as a financing tool and the choice of the specific type of instrument by the company.
\end{abstract}

KAUJIE Classification: K3, L4

JEL Classification: G23

(C) 2018 JIBM. All rights reserved.

\section{INTRODUCTION}

Many well-known and established companies, besides availing lines of credit from banks, can and do raise external financing for expanding businesses through issuance of instruments, such as commercial paper, corporate bonds, or syndicated credit. A company with good financial position, known track record with lower credit risk, progressive business development and expansion could get better corporate rates for financing.

Before the availability of Shari' 'ah compliant instruments of financing, the Muslim entrepreneurs were having limited choices, if any, in raising financing without involving the interest payments. The companies were constrained in external financing for their growing needs of financing, if they chose to stay away from riba, which is abhorred and forbidden in the Islamic Shari'ah.

In this study, the target company for analysis is a well-known company incorporated in Pakistan in the 1950s is operating successfully in textile, chemicals and energy sectors. It

${ }^{*}$ Corresponding author: Zohra Jabeen

${ }^{\dagger}$ Email: zohra.jabeen@imsciences.edu.pk 
is a well-managed company with good business prospects and with a reputable ownership and management teams. With their existing interest based debt on the one hand, and their expansion needs plus the on-going energy crisis in the country on the other (1996), they needed financing, but the matter was getting stalled due to non-availability of financing alternatives to interest, and that too of equity nature.

The founding Chief Executive of the Company was getting very uneasy about the interestbased borrowing the company had availed as well as the mounting pressure of further financing, which he did not want through interest-based facilities. Therefore, he discussed with his Chief Financial Officer the company's current debt position, which stood at more than Rs.100 Million plus long-term project financings. In addition, they needed to expand their caustic soda plant capacity as well as their own energy generating plants.

During the search for Shari'ah compliant alternatives, they attended a lecture session delivered by a Shari 'ah scholar expert in mu 'âmalàt. It was a general lecture for all attendees. The CEO urged his CFO to explore this matter further, in order to extricate the company from debt-based financing and further follow mechanisms that are free from riba. The CFO discussed the matter with the Shari' ${ }^{\prime}$ ah scholar as also wit Islamic bankers.

The Islamic bankers introduced debt or lease based financing (murābahah or ijārah), but the CFO was skeptical about them particularly because they need project finance. At the back of his mind he was thinking about the possibility of equity based term finance or any other PLS technique.

The CEO also urged him to explore the possibilities further. The CFO held detailed meetings with different Islamic bankers, Chartered Accountants and Shari' 'ah Scholars, in order to understand the Shari 'ah parameters for financing products and their nature of and applications in different situations. He also discussed the existing debt of the company and their future financing needs. The company was doing very well, and prospects for future demand of their products' demand were also bright. The company also intended to diversify its chemicals business, and set-up their own energy production plants.

From the bankers' perspective, the company is a high rated business concerned, and its management and owners have been enjoying a good market reputation too. Financing such a company was not a problem. However, the company was more interested in repaying its existing interest-based debt first prior to getting Shari ${ }^{\circ}$ ah compliant project finance. Some of the discussions in this regard are as follows:

a) If their debt pertains to working capital financing like running finance, then they must repay the loan first, as an Islamic bank was not able to re-finance the working assets they already had bought.

b) If their debt is a long-term debt, say for machinery financing, and the book value of the machinery covers the outstanding loan amount, then after the company retires its debt, the same can be financed through ijärah financing, by selling the assets to the bank.

c) If the debt against machinery or other fixed asset is outstanding, but the book value of the asset is very low, then Islamic financing cannot be provided against that asset, as Islamic Finance cannot have a fictitious amount as the price of the underlying asset.

d) The existing debt has to be cleared first. One possibility for Islamic banks can be to retire 
the debt through their own funds and then do some long-term financing with the company. However, this will have high risk factor. Perhaps more than one bank can take up the loan and do collective financing with the company. However, for that they have to take sound collaterals from the company and the cost of such a business would also be higher than normal transactions.

e) If a sale and lease back arrangement is used, the company would sell its assets to the bank and the asset will be resold to the company at a markup.

The Islamic bankers discussed their products modalities with the CFO and CEO, together. They explained to them that based on the list of classical contracts available in Islamic figh, they customized the products according to the clients' needs. For instance, some of their clients who wish to have working capital financing for their inventory on a recurring basis, for them, they designed deferred muräbahah, with a competitive rates. There is no harm in having a similar rate to the conventional banking industry, because of the subject of the transaction changes from loan to a trade in Shari 'ah permissible assets. They further discussed these points. Their debt was partly related to working capital and partly to machinery whose book value was very low, such that it could not suffice in totality as an underlying asset for Islamic financing. The sale and lease back mechanism was explained to them, but this did not convince the CEO as well as the CFO. They did not consider the sale and lease-back as a sound transaction for the purpose. They were willing to provide them the collaterals and their bank accounts as collaterals for facilitation, but were inclined for equity-based products.

After further discussions, one Islamic banker came up with the idea of Term Finance Certificates, to be privately placed with the Islamic banks which would retire their loans. This got them interested. They were told that there were some Term Finance Certificates (TFCs) already issued by credible companies. TFC's issuance notes are at a level of subordinated equity and are usually listed on the Stock Exchange. There are daily bid (buy) and offer (sell) prices for a range of TFCs. They are rated by the rating agencies, like PACRA and JCR-VIS. However, they are unsecured and subordinated instruments. TFC's principal is gradually redeemed over its tenor, unlike all principal payment at maturity in the end.

Both the CEO and CFO of the company liked the idea of TFC but they asked about the nature of TFCs. They were informed that currently the TFCs have bond like features as they give periodic coupons, usually benchmarked to SBP discount rate or the auction yield of Pakistan Investment Bonds (PIB) of equivalent maturity plus the added risk spread depending upon the risk profile of the issuer. These are issued by credible companies and at the time of issuance, they agree and announce the rate of return on the TFCs. Corporate TFCs are gaining momentum among institutional investors, like pension funds, provident funds, banks and insurance companies. Their yield is higher than National Saving Certificates and Bank deposits ${ }^{1}$. The TFCs can be privately placed with banks too. In this case, the TFCs can be issued by the company for the loans bought over by the Islamic Banks. Then they would be repaid by the company over a lag period of say one year or more.

\footnotetext{
${ }^{1}$ According to the State Bank of Pakistan a "participation term certificate is a certificate or note evidencing ownership by the holder, but without voting rights of a stated percentage of a "package" or "pool" of mortgages which pays interest at a stated rate. The term finance certificates are redeemable in quarterly / half yearly installments".
} 
However, the CFO was of the view that repayment mechanism of such TFCs and announcing a profit rate beforehand would again make them interest-based. The bankers agreed with his comments. "Can we not have TFCs based on mushārakah?" asked the CFO. The Bankers replied that there had been no mushärakah based TFCs up to that time, but they would think about it and discuss further.

Later-on the Islamic bankers discussed the possibility of buying over their loan from the conventional banks and also the matter of mushärakah based TFCs, among themselves and their product development teams. They also needed the opinion of the Shari'ah advisors on both maters. Regarding the mushärakah based TFCs, their product development teams sat together to chalk out possibilities. They discussed that the client wanted the product to be preferably based on profit and loss principle. The regulations expert at the bank highlighted the constraints due to banking regulations that do not allow banks to put the depositors' money in a risk beyond safe levels like deferred muräbahah, ijärah and others. He argued that giving funds on profit and loss sharing would be very risky as well as costly. One of the bankers discussed the possibility of reducing the risk by arranging a syndicated financing collectively. This idea was discussed for working as a consortium to distribute the risk as well as cost of funding. Finally, after much deliberation, it was agreed that banks were allowed to retire the interest bearing loans and arrange Shari 'ah based financing for the client. Two banks agreed to take up the project collectively on the basis of mushärakah.

Regarding the first issue of buying over their loan from the conventional banks, they communicated the matter to their Shari 'ah supervisor, who was going to a meeting of the International Shari' ${ }^{\prime}$ ah scholars. The Shari 'ah scholar presented the matter at their meeting and all the scholars discussed the matter. After a lot of deliberations, it was resolved collectively that, in order to take someone out of interest based financing, the Islamic banks may be allowed to use their funds to pay off the interest-bearing loans and bring the companies out of interest to Shari' 'ah-based funding, as a matter of goodness to them. However, the companies have to do Shari' 'ah based funding after that and not keep switching between Shari' 'ah based and interest-based financing.

The two banks agreed to take up the outstanding amount of loan at par value. The next step was to discuss whether mushärakah TFCs or (TFC) could be issued? They started discussing the MTFC with the client. The client was of the view that although TFCs are a close alternative, but their modalities do not make them exactly equity, may be they are subordinated equity, just like any subordinated debt. The CFO said, "We cannot afford getting rid of one debt, and yet take another debt". The Islamic bankers were of the view, on the other hand, that the mushärakah based financing based on profit and loss sharing would be extremely risky and they might incur the loss even. However, the client showed the company's record to them since 1990, proving that they had never incurred any loss. Then they discussed that the banks would likely to have a higher profit margin for them to start with as it is a high-risk venture for them and they are doing it for the first time. The client agreed that they would be willing to genuinely share the profit with the bank.

According to the principle of musharakah, the profit and loss would be shared among the shareholding parties, i.e., the banks and the client. Although the banks preferred repayment 
of principal amount after one year, the client pushed for three years period in order to achieve the capacity to repay. The equity investment of the banks would be repaid over time in three tranches, following the principle of TFCs. The client requirement was Rs. 150 million. The CFO had done his financial projections based on how they would repay the amount in three years' time.

The Islamic bankers suggested terms regarding profit and loss sharing in two tiers. Their profit share would be $15 \%$ to $18 \%$ of operating profit say if the profits is equal to or below Rs.100. In case of operating profit beyond Rs 100 million, they would leave a major portion of profit to the client, as an incentive and take only $3.33 \%$. From that amount too, they will keep half the amount as a takâful reserve. The CFO and the Islamic bankers tried to negotiate the rate of profit but finally agreed at $15 \%$. The banks would require the pari passu charge on their plant and machinery to the tune of Rs. 150 million till the MTFC's are fully redeemed, which was agreed. Through MTFC arrangement, the company and the Islamic banks are considered equity holders, but the nature of their equity would be such that they would not have any voting rights, and when the company pays off the equity and the profit accrued, over time, then it would leave, would not remain the equity holders.

The Islamic banks would be paid by the company in three tranches beginning from three years after the issues of MTFCs (i.e., 31st December 2002) Commencing from three years after issue, $33 \%$ of the amount of MTFC shall be redeemed at each redemption date, meaning Rs. 50 million each).

Redemption periods: First 33\% in December 31, 2002, i.e. Rs 5,000 per unit, Second 33\% in December 31, 2003, i.e. Rs 5,000 per unit, Third 33\% in December 31, 2004, i.e. Rs 5,000 per unit,

The trustee of the transaction shall be an Islamic Bank Limited by way of Trust Deed and the trust conditions shall be that:

1) Trustee shall appoint one director on Board to represent the MTFCs holders equivalent to Rs 150 million, on fixed assets of company, created in favor of Trustee to protect the MTFCs holders.

2) MTFCs would be subject to zakāh deductions and deductions of withholding income tax.

3) A charge of Rs. 150 million on fixed assets of the chemical division was registered in favor of the Trustee for the benefit of the MTFC holders in case of any eventuality. If all goes well and the company is able to repay the first MTFC well on time, there shall be another tranche of MTFCs, preferably in 2002. Its terms and conditions shall depend on the prevailing conditions and success of the previous MTFC. This would be done to finance expansion of their caustic soda plant which would be called MTFC II. It may be publicly placed.

\section{CONCLUSION}

This study depicts the case of a need for interest free financing by an entrepreneur of a large manufacturing enterprise. This was at a time when Islamic banking was not common in the country. However, Islamic finance had started in many countries and Islamic investments companies and well versed Shari'ah scholars, who were expert in transactions that were 
available in the country. By consulting various experts in their fields and discussing their requirement, the company, with the help of Islamic Financial institutions was finally able to convert its interest-bearing loans into Islamic financing of its own preference, i.e., MTFCs. The company's performance improved as a result of the arrangement and the bankers too made excellent earnings. With a very good relationship to build and providing a profit much higher than the conventional loans, the company was able to continue with another MTFC for its expansion needs, i.e., Caustic soda plant.

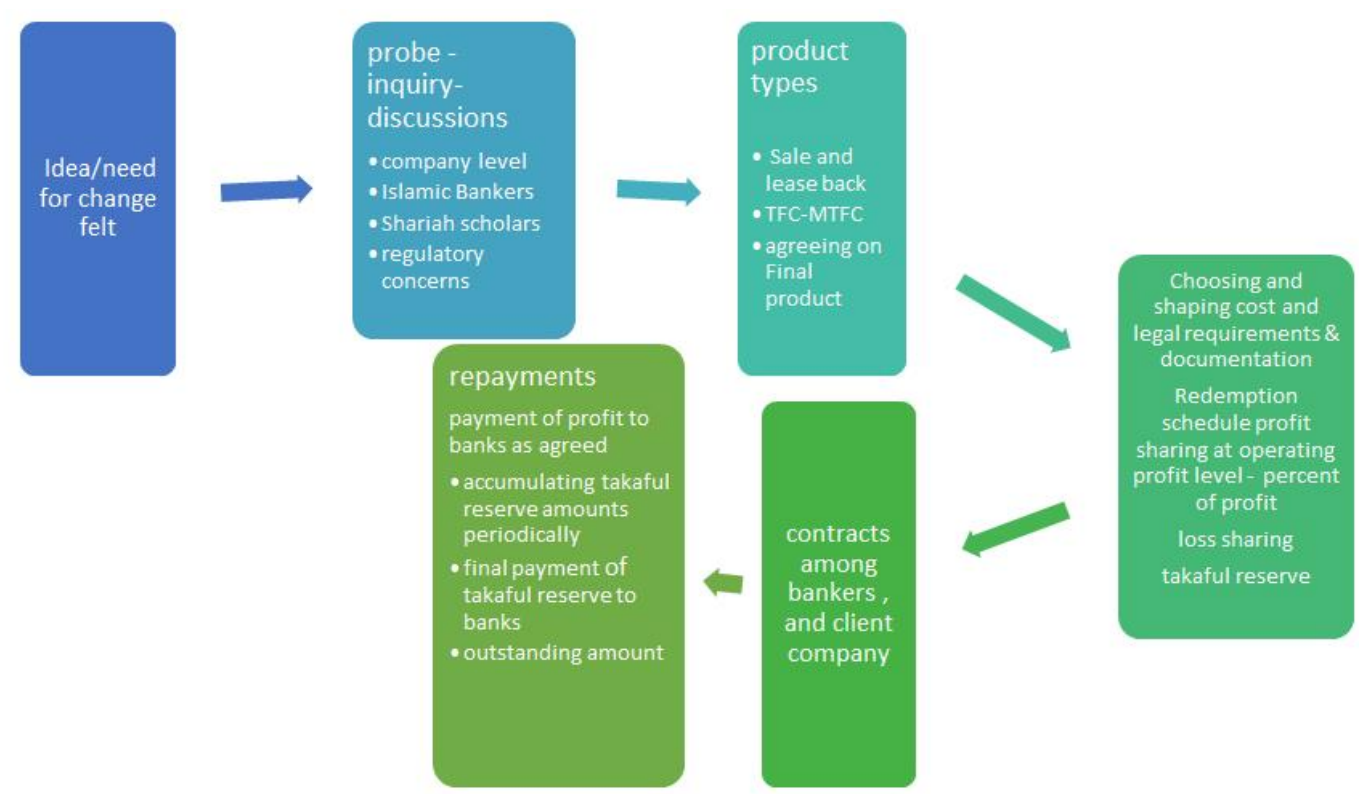

FIGURE 1. Product process flowchart

Given below is the profit profile of the company before and after the transition to Shari 'ah based financing.

TABLE 1

Profit profile of the company before the transition to Shari'ah based financing

\begin{tabular}{clllcc}
\hline \hline Star Enterprises & & & & & Rs. In Millions \\
\hline Year End & Equity & Operating Profit & Net Profit & Gross Level ROE & ROE \\
\hline 1990 & 104 & 69 & 49 & $66 \%$ & $47 \%$ \\
1991 & 133 & 97 & 74 & $73 \%$ & $56 \%$ \\
1992 & 182 & 141 & 107 & $77 \%$ & $59 \%$ \\
1993 & 261 & 160 & 113 & $61 \%$ & $43 \%$ \\
1994 & 290 & 138 & 64 & $48 \%$ & $22 \%$ \\
1995 & 336 & 223 & 103 & $66 \%$ & $31 \%$ \\
1996 & 357 & 239 & 113 & $67 \%$ & $32 \%$ \\
1997 & 421 & 261 & 120 & $62 \%$ & $29 \%$ \\
1998 & 477 & 280 & 182 & $59 \%$ & $38 \%$ \\
\hline \hline
\end{tabular}

After the transition: 
TABLE 2

Profit profile of the company after the transition to Shari'ah based financing

\begin{tabular}{clllcc}
\hline \hline Star Enterprises & & & & & Rs. In Millions \\
\hline Year End & Equity & Operating Profit & Net Profit & Gross Level ROE & ROE \\
\hline 1997 & 421 & 261 & 120 & $62 \%$ & $29 \%$ \\
1998 & 477 & 280 & 182 & $59 \%$ & $38 \%$ \\
1999 & 348 & 303 & 221 & $87 \%$ & $64 \%$ \\
2000 & 492 & 491 & 406 & $100 \%$ & $83 \%$ \\
2001 & 612 & 435 & 347 & $71 \%$ & $57 \%$ \\
2002 & 751 & 425 & 344 & $57 \%$ & $46 \%$ \\
2003 & 971 & 388 & 286 & $40 \%$ & $29 \%$ \\
2004 & 1219 & 488 & 371 & $40 \%$ & $30 \%$ \\
2005 & 1473 & 691 & 507 & $47 \%$ & $34 \%$ \\
2006 & 1658 & 519 & 358 & $31 \%$ & $22 \%$ \\
2007 & 1922 & 894 & 537 & $47 \%$ & $28 \%$ \\
\hline \hline
\end{tabular}

\section{Further Research and Analysis Questions}

1) What is a MTFC? And how is it different from a conventional TFC?

2) What was the need for devising a MTFC?

3) In addition to the religious consideration, what can you infer to be the advantage/or and disadvantage of MTFC?

4) What was the financial benefit to the company and the Banks' in the converting the loan to MTFC, at the prescribed rates? Do calculations.

5) What was the strategic benefit to the financiers?

6) What was/were the new Shari'ah input(s) and declaration(s), that eased the process of transition from interest-based loan to Shari 'ah based financing?

7) Calculate the profit accrued to the Banks as a result of the transaction and find the KIBOR and Banks' corporate lending rates in the same time period in Pakistan.

\section{REFERENCES AND SUGGESTED READINGS}

Ayub, M. (2002). Islamic banking and finance: Theory and practice. Karachi, Pakistan: State Bank of Pakistan.

Ayub, M. (2007). Understanding Islamic finance. London, UK: John Wiley and Sons. 
TABLE 3

Answer to question 7

\begin{tabular}{|c|c|c|c|c|c|c|c|c|c|c|}
\hline & $\begin{array}{l}\text { Operating } \\
\text { Profit }\end{array}$ & $\begin{array}{l}\text { Less Rs } \\
100 \mathrm{M} \\
\text { Profit }\end{array}$ & $\begin{array}{l}\text { Remaining } \\
\text { Operating } \\
\text { Profit }\end{array}$ & $\begin{array}{l}\text { Profit @15\% } \\
\text { of } 100 \mathrm{M}\end{array}$ & & & $\begin{array}{l}\text { Takaful } \\
\text { Reserve }\end{array}$ & $\begin{array}{l}\text { Profit } \\
\text { Earned by } \\
\text { Banks }\end{array}$ & $\begin{array}{l}\text { Profit \% } \\
\text { Earned by } \\
\text { Banks }\end{array}$ & $\begin{array}{l}\text { Outstanding } \\
\text { MTFC } \\
\text { Amount }\end{array}$ \\
\hline & & & & & $3.33 \%$ & $\begin{array}{l}\text { half of } \\
3.33 \%\end{array}$ & & $\begin{array}{l}\text { Rs. Mil- } \\
\text { lion }\end{array}$ & $\%$ & \\
\hline & A & B & $\mathrm{C}$ & $d=b \times 15 \%$ & $e=c \times 3.33 \%$ & $\mathrm{f}=\mathrm{e} / 2$ & $g=f$ & & & \\
\hline 1999 & 303 & 100 & 203 & 15 & 6.7599 & 3.37995 & 3.37995 & 21.7599 & $14.51 \%$ & \\
\hline 2000 & 491 & 100 & 391 & 15 & 13.0203 & 6.51015 & 6.51015 & 28.0203 & $18.68 \%$ & \\
\hline 2001 & 435 & 100 & 335 & 15 & 11.1555 & 5.57775 & 5.57775 & 26.1555 & $17.44 \%$ & 150 \\
\hline 2002 & 425 & 100 & 325 & 15 & 10.8225 & 5.41125 & 5.41125 & 25.8225 & $26.00 \%$ & 100 \\
\hline 2003 & 388 & 100 & 288 & 15 & 9.5904 & 4.7952 & 24.5904 & 24.5904 & 49.74 & 50 \\
\hline
\end{tabular}

